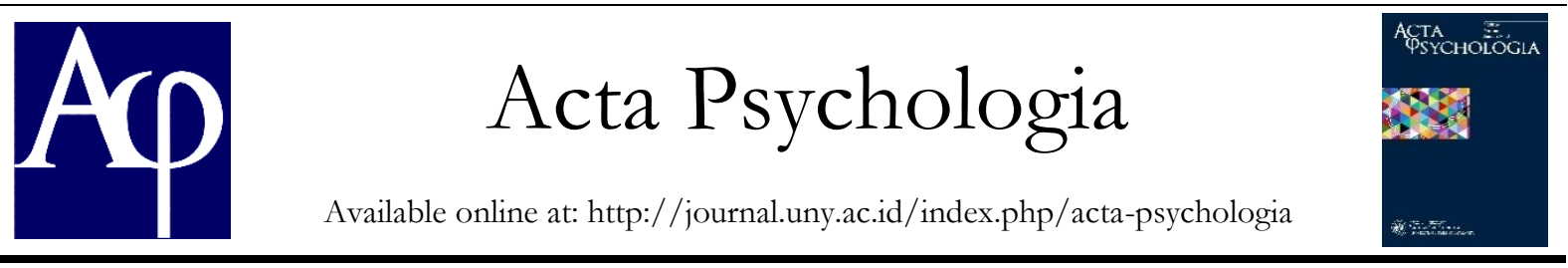

\title{
Subjective Well-Being pada Ibu Tunggal Dewasa Awal yang Bercerai
}

\author{
Dwi Wahyu Puji Lestari \\ Jurusan Psikologi, Fakultas Ilmu Pendidikan, Universitas Negeri Yogyakarta; \\ Jl. Colombo No. 1 Sleman Yogyakarta, 55281 \\ dwiwahyupujilestari@gmail.com
}

\begin{abstract}
Abstrak
Penelitian ini bertujuan untuk mengetahui gambaran subjective well-being (SWB) pada ibu tunggal dewasa awal yang bercerai. Pendekatan penelitian ini menggunakan pendekatan kualitatif jenis studi kasus. Subjek penelitian adalah 4 orang wanita berusia 20-40 tahun yang telah bercerai dan memiliki anak. Metode pengumpulan data menggunakan wawancara. Teknik analisis data menggunakan reduksi data, display data, dan kesimpulan. Uji keabsahan data menggunakan teknik triangulasi sumber dan member checking. Hasil penelitian menunjukkan subjek memiliki SWB bervariasi, yaitu ada persamaan dan perbedaan pada subjek. Keempat subjek memiliki afek positif lebih dominan dibandingkan afek negatif serta memiliki kepuasan hidup. Keempat subjek merasa senang dengan kehidupannya sebagai ibu tunggal. Keadaan sedih, marah, serta khawatir terjadi ketika hendak memutuskan bercerai ataupun sesaat setelah bercerai. Seiring berjalannya waktu mereka menerima kehidupan masa lalu mereka, menjalani kehidupan sekarang dengan bahagia, dan memiliki tujuan untuk masa depannya.
\end{abstract}

Kata Kunci: subjective well-being, ibu tunggal, dewasa muda, bercerai

\begin{abstract}
This research aims to find out an overview of subjective well-being from divorced single mothers. This research is a case study with a qualitative approach. The research's subjects are 4 women from 20-40 years old that has been divorced and have children. Data collected using the interview method and analyzed by data reduction, data display, and conclusions verification. The validity tests of the data use source triangulation techniques and member checking. The results of this study showed that subjects have various subjective well-being but also have some similarities. The subject's positive affect is more dominant than the negative affect and also have life satisfaction. This can be seen from both of the subjects who are currently happy with their lives as single mothers. The state of sadness, anger, or worry only occurred at the time they decided to divorce or shortly after the divorce. As time goes by, they can accept their past lives, live their lives joyfully, and have goals for their futures.
\end{abstract}

Keywords: subjective well-being, single mothers, early adult, divorced

\section{Pendahuluan}

Menurut Santrock (2012) masa dewasa awal dimulai pada umur awal 20 tahun sampai umur 40 tahun dan merupakan masa pembentukan kemandirian ekonomi, pribadi, serta perkembangan karier dan intimasi menjadi lebih penting. Salah satu tugas perkembangan pada masa dewasa awal ini adalah hubungan sosial, ketika dalam berhubungan sosial individu dewasa awal mereka lebih siap untuk komitmen dan akhirnya menikah (Ranta, 2015). Harapannya pada masa ini individu dapat memiliki hubungan sosial dan berkomitmen untuk menikah dan membentuk keluarga kemudian berusaha untuk mencapai tujuan yang hendak dicapai bersama.

Namun kenyataannya, tidak semua keluarga dapat menjalankan tujuan bersama dengan lancar. Hambatan dalam keluarga dapat terjadi apabila tidak ada kesamaan 
tujuan yang akhirnya dapat menjadi penyebab perselisihan dan keretakan dalam keluarga. Semakin banyak permasalahan yang terjadi dalam keluarga, tidak hanya permasalahan karena perbedaan tujuan namun juga mengenai kebutuhan rumah tangga yang semakin meningkat seiring dengan perkembangan yang terjadi. Kebutuhan hidup yang tidak terpenuhi dan perbedaan tujuan yang tidak teratasi berakibat menjadi pokok permasalahan dalam rumah tangga. Tidak adanya penyelesaian yang berarti mengenai permasalahan tersebut dapat menjadi alasan pasangan untuk berpisah atau bercerai.

Undang-Undang No. 1 Tahun 1974 pasal 38 mengenai putusan perkawinan serta akibatnya menjelaskan bahwa perkawinan dapat putus karena kematian, perceraian, dan atas putusan pengadilan. Menurut data Pengadilan Tinggi Agama (dalam Julijanto, Masrukhin, \& Hayatuddin, 2016) terdapat empat faktor penyebab perceraian di kalangan pasangan rumah tangga di Indonesia, yaitu moral, meninggalkan kewajiban, menyakiti jasmani/rohani, dan terus-menerus berselisih.

Data Badan Pusat Statistik (2018) menyebutkan angka perceraian di Indonesia pada tahun 2015 sebanyak 353.843 kasus, tahun 2016 sebanyak 365.654 kasus, dan tahun 2017 sebanyak 374.516 kasus. Di daerahJawa Tengah pada tahun 2015 terdapat 71.901 kasus, 2016 menurun menjadi 71.373 , dan tahun 2017 menurun lagi menjadi 69.857 kasus. Sementara pada grafik 3 menjelaskan bahwa pada daerah Wonogiri kasus perceraian mengalami peningkatan, tahun 2015 sebanyak 1.429 kasus, 2016 meningkat menjadi 1.455 kasus, 2017 terdapat 1.600 kasus, dan pada 2018 hingga bulan Agustus terdapat 3.001 kasus (Panca, 2018). Secara umum, dapat dikatakan bahwa angka perceraian di Indonesia meningkat.

Menurut hasil wawancara dengan salah satu masyarakat di Wonogiri pada tanggal 24 Desember 2018, fenomena yang terjadi di sekitar informan tinggal adalah keadaan wanita setelah terjadinya perceraian. Setelah memutuskan bercerai, para wanita tersebut berusaha keras mencari cara untuk menyambung hidupnya beserta anaknya. Mantan suami atau pihak laki-laki ketika sudah bercerai seolah-olah lepas tanggung jawabnya terhadap anak, tidak memberi nafkah pada anak, tidak menanyakan kabar keadaan anak, bahkan dengan waktu singkat memutuskan untuk menikah kembali setelah perceraian.

Perceraian menjadi salah satu faktor penyebab banyaknya orangtua tunggal di Indonesia. Orangtua tunggal merupakan orang yang melakukan tugas sebagai orangtua (ayah atau ibu) seorang diri, karena kehilangan/terpisah dengan pasangannya (Gunawan dalam Ayuwanty, Mulyana, \& Zainuddin, 2018). Jika seorang ibu, maka disebut ibu tunggal. Semua perempuan tentu tidak menginginkan adanya perpisahan dalam keluarga sehingga menjadi seorang ibu tunggal, tetapi hal itu dapat menimpa siapa saja. Seorang ibu tunggal akan mengalami perubahan dalam kehidupannya.

Perubahan-perubahan yang terjadi menjadikan ibu tunggal beradaptasi dengan kondisi yang baru yakni penambahan peran dan serangkaian tugastugas ganda yang harus dilakukan (Nisa \& Lestari, 2017). Seorang ibu tunggal harus tetap menghidupi anaknya seorang diri tanpa adanya suami dan menghadapi situasi yang sangat berat. Kondisi ini sangat tidak mudah untuk dihadapi seorang diri oleh ibu tunggal, yang menuntut seorang ibu harus siap walaupun sebenarnya tidak siap, untuk tetap kuat menjalani kehidupan agar anakanaknya tidak terpuruk.

Peran ibu tunggal sebagai kepala keluarga sangatlah penting. Ibu tunggal tersebut akan melakukan peran gandanya sebagai kepala keluarga yang memliki kewajiban untuk memenuhi kebutuhannya serta kebutuhan anak-anaknya. Selain itu, 
ibu tunggal berperan sebagai seorang ibu yang mendidik anak-anaknya sekaligus juga melakukan pekerjaan rumah tangga. Meski banyak ibu tunggal yang mengalami kesulitan dan harus berusaha keras memenuhi kebutuhan anak-anaknya, namun kesejahteraan bukan hanya diukur dari materi saja. Perasaan-perasaan positif dan rasa kepuasan terhadap hidup pada ibu tunggal juga dapat mengukur kesejahteraan yang dirasakan secara subjektif pada ibu tunggal atau yang biasa disebut subjective well-being.

Subjective well-being (selanjutnya disingkat SWB) yaitu melibatkan evaluasi subjektif dari status seseorang saat ini di dunia. Subjective well-being sebagai kombinasi (dari beberapa aspek) yang berdampak positif (tanpa adanya pengaruh negatif) dan kepuasan hidup secara umum. Istilah subjektif sering digunakan sebagai sinonim untuk kebahagiaan dalam literatur psikologi. Hampir tanpa kecuali, kebahagiaan merupakan kata yang lebih mudah diakses atau digunakan dalam perspektif populer sebagai pengganti istilah SWB (Lopez dan Snyder, 2007). Subjective well-being terdiri dari afek positif, afek negatif, dan kepuasan hidup. Individu dengan SWB yang baik akan memiliki kemampuan untuk mengontrol emosi dan menghadapi berbagai peristiwa.

Wiranti dan Sudagijono (2017) menyatakan bahwa bentuk kepuasan ibu tunggal akan hidupnya saat ini adalah meski hidup sendiri bersama dengan anaknya, namun ibu tunggal merasa mampu untuk memenuhi kebutuhan hidup sehari-hari tanpa harus bergantung kepada mantan suaminya. Ibu tunggal juga merasa bersyukur dengan kondisinya saat ini serta merasa bangga dengan hasil kerja keras yang telah dicapainya. Perasaan bersyukur dan bangga menunjukkan adanya emosi positif dalam diri partisipan. Emosi positif ini bersama dengan kepuasan hidup menunjukkan adanya kesejahteraan subjektif yang dimiliki oleh ibu tunggal.
Kaneez (2015) menjelaskan beberapa hasil mengenai persepsi SWB pada perempuan yang bercerai. Pertama, perempuan yang bercerai dari lingkungan sosial budaya yang sama telah menghadapi kesulitan yang hampir sama yaitu mengenai sosial, keuangan, emosional dan Kesehatan terkait setelah perceraian. Kedua, wanita yang bercerai dibandingkan dengan wanita yang sudah menikah dilaporkan lebih banyak keluhan ketidakbahagiaan dan kekhawatiran yang berkaitan dengan aspek kehidupan mereka. Ketiga, selain kesengsaraan sosioekonomi, mayoritas perempuan yang bercerai telah menekankan trauma psikologis yang mereka rasakan sebagai akibat dari bercerai. Keempat, emosi / konsekuensi negatif seperti itu berdampak buruk pada kesehatan fisik dan mental mereka yang berakibat pada kesehatan psikologis yang buruk. Kelima, berhubungan dengan stigma sosial, ketidakamanan emosional dan ketidakpastian ekonomi yang membuat perempuan yang bercerai lebih rentan terhadap masalah psikososial dan mengurangi kesejahteraan subjektif mereka dalam periode pasca-perceraian.

Selain dari hal yang telah dijelaskan, Amato (dalam Shields \& Wooden, 2003) menjelaskan individu yang bercerai memiliki tingkat SWB yang berkurang. Hal tersebut dikarenakan oleh proses perpisahan dan perceraian adalah hal yang sangat membuat stress, walaupun sudah di antisipasi. Perceraian juga sering diasosiasikan dengan kesulitan, seperti kesepian dan meningkatnya kekhawatiran pada masalah finansial.

Hawkins dan Booth (2005) membandingkan individu yang tidak menikah, individu yang pernikahannya tidak bahagia memilki tingkat kebahagiaan rendah, kepuasan hidup dan harga diri serta banyak gejala stress psikologis dan kesehatan yang buruk. Individu yang bercerai dan menikah kembali memiliki tingkat kebahagiaan yang lebih baik dan individu yang bercerai dan tidak menikah 
lagi memiliki tingkat kepuasan hidup, harga diri, dan kesehatan yang baik dibandingkan dengan individu yang pernikahannya tidak bahagia.

Diener (2009) menyatakan bahwa pernikahan memiliki korelasi yang positif dan merupakan faktor yang penting dalam hubungannya dengan SWB. Keadaan di masyarakat sekarang mengenai ketiadaan penyelesaian dalam permasalahan membuat mereka memutuskan untuk bercerai. Perceraian memberi dampak bagi semua bagian dari keluarga, termasuk ibu. Banyak stigma negatif pada masyarakat mengenai ibu tunggal yang bercerai. Ibu tunggal harus menghadapi stigma tersebut bersamaan dengan permasalahan yang harus dihadapi dalam kehidupan seharihari. Setelah bercerai ibu tunggal akan mencari uang untuk memenuhi kebutuhan hidup dirinya maupun keluarganya. Ibu tunggal juga harus memikirkan permasalahan mengenai anaknya, permasalahan di tempat kerja, maupun di lingkungan tinggal sendiri. Tidak jarang ibu tunggal juga dijauhi dari lingkungan sosial setelah bercerai hingga merasakan kesepian. Di samping permasalahanpermasalahan dan perasaan kesepian, ibu tunggal juga merasakan perasaan-perasaan positif. Perasaan positif yang dirasakan ibu tunggal seperti perasaan lega setelah bercerai, kebanggaan karena dapat menopang hidup dengan kerja kerasnya, hingga merasakan kepuasan karena dapat melalui hal-hal yang berat dalam hidupnya. Banyak hal yang dihadapi oleh ibu tunggal sehingga terdapat kemungkinan ibu tunggal merasakan kebahagiaan atau tidak setelah menghadapi kehidupannya bercerai.

Berdasarkan hal-hal yang telah dijelaskan, penelitian mengenai SWB pada ibu tunggal dewasa awal yang bercerai masih sedikit ditemui. Oleh karena itu, peneliti ingin mengetahui bagaimana SWB pada ibu tunggal dewasa awal yang bercerai? Apa saja afek positif, afek negatif, kepuasan hidup ibu tunggal dewasa awal yang bercerai? Permasalahan apa saja yang mereka alami ketika menjadi ibu tunggal setelah bercerai? Siapa yang mendukung keadaan mereka sekarang? Apa strategi yang mereka lakukan untuk menghadapi keadaannya sebagai ibu tunggal?

\section{Metode Penelitian}

\section{Jenis Penelitian}

Penelitian ini menggunakan pendekatan kualitatif dengan jenis studi kasus.

\section{Waktu dan Tempat Penelitian}

Penelitian ini dilakukan pada bulan Januari 2019 di Wonogiri.

\section{Subjek Penelitian}

Subjek dalam penelitian ini adalah sebanyak 4 orang. Subjek penelitian dipilih secara purposive, dengan syarat wanita bercerai secara hukum, berusia 20-40 tahun, dan memiliki anak.

\section{Instrumen dan Teknik Pengumpulan Data}

Teknik pengumpulan data dalam penelitian ini adalah menggunakan wawancara jenis semi terstruktur dimana pihak yang diajak wawancara diminta pendapat dan ide- idenya.

\section{Teknik Analisis Data}

Peneliti menggunakan model yang dikembangkan oleh Miles dan Huberman (dalam Herdiansyah, 2015) dalam menganalisis data yaitu reduksi data, display data, penarikan kesimpulan, dan atau verifikasi. Dalam reduksi data terjadi proses penggabungan data yang diperoleh menjadi satu bentuk tulisan yang akan dianalisis. Hasil dari rekaman wawancara yang didapatkan oleh peneliti diformat menjadi bentuk verbatim wawancara. Setelah menajdi verbatim wawancara, langkah selanjutnya adalah melakukan display data. Dalam display data, data setengah jadi yang sudah seragam dalam bentuk tulisan dan sudah memiliki alur tema yang jelas diolah ke dalam matriks kategorisasi sesuai tema- 
tema yang sudah dikelompokkan dan dikategorikan, serta akan memecah tematema tersebut ke dalam bentuk yang lebih konkret dan sederhana yang disebutkan yang disebut dengan sub-tema, yang diakhiri dengan pemberian kode (coding) dari sub-tema tersebut sesuai dengan verbatim wawancara yang sebelumnya telah dilakukan. Setelah di beri kode ditariklah kesimpulan berisi tentang uraian dari seluruh sub-kategorisasi tema yang tercantum pada tabel kategorisasi dan koding yang sudah terselesaikan, disertai dengan quote verbatim wawancaranya.

\section{Hasil Penelitian dan Pembahasan}

Hasil dari penelitian ini didapatkan bahwa terdapat afek positif, afek negatif, serta kepuasan hidup yang terjadi pada ibu tunggal dewasa awal yang bercerai. Afek positif yang ada pada mereka adalah mengalami perasaan senang dan bahagia dengan keadaannya sebagai ibu tunggal. Mereka merasa bangga karena merasa dapat membesarkan anaknya dengan baik. Rasa bangganya diikuti perasaan bersyukur karena anaknya dapat berprestasi. $\mathrm{Hal}$ tersebut membuat ibu tunggal menjadi lebih bersemangat dalam menjalani kehidupan demi anaknya. Anak menjadi alasan mereka untuk lebih semangat dalam menjalani keadaan sebagai ibu tunggal seperti yang diutarakan oleh Wiranti dan Sudagijono (2017) bahwa bagi ibu tunggal anak adalah segalanya dan merupakan alasan terkuat bagi ibu tunggal tetap bersemangat menjalani hidup serta kemampuan ibu tunggal merawat dan membesarkan anak akan menimbulkan emosi positif berupa perasaan bangga dan bahagia. Menurut penjelasan, perasaan senang, bangga, dan bersemangat beraktifitas untuk anaknya menguasai afek positif ibu tunggal.

Afek negatif yang ada pada ibu tunggal adalah perasaan khawatir, marah, sedih, tertekan, dan iri dengan kehidupan orang lain. Ketika hendak memutuskan untuk bercerai, ibu tunggal dewasa awal merasa khawatir dengan kemampuan mereka membesarkan anaknya dan merasa marah dengan mantan suaminya. $\mathrm{Hal}$ tersebut sejalan dengan yang dijelaskan oleh Anggraheni (2016) bahwa pada masa awal menjalani peran sebagai ibu tunggal seringkali membuat mereka menjadi tidak yakin dengan diri mereka atau kemampuan mereka untuk membesarkan anak nantinya, namun seiring berjalannya waktu ia akan semakin terbiasa dan mampu menemukan kebahagiaan mereka. Tidak jarang mereka merasa sedih dan tertekan dengan keadaan mereka sebagai ibu tunggal. Ketika melihat keluarga lain yang utuh, ibu tunggal terkadang merasa iri, namun mereka juga masih khawatir untuk memiliki keluarga kembali meskipun mereka ingin. Walter (dalam Aisyah 2012) menyatakan bahwa perceraian akan menimbulkan dampak yang besar terhadap perempuan, perasaan shock, penghianatan, kehilangan kendali, merasa menjadi korban, rasa tidak aman, amarah, keinginan untuk membalas dendam kepada mantan suami. Hal tersebut akan menimbulkan trauma seperti yang disampaikan oleh Kaneez (2015) bahwa mayoritas perempuan yang bercerai akan memiliki trauma psikologis akibat bercerai. Keadaan ibu tunggal saat ini, sesekali mereka merasakan afek negatif seperti rasa sedih, tertekan, dan iri dengan keadaan orang lain atau keluarga yang utuh.

Kepuasan hidup yang dirasakan ibu tunggal dewasa awal yang bercerai adalah sekarang mereka dapat menerima keadaan sebagai ibu tunggal. Mereka melihat hal dimasa lalu sebagai sebuah pelajaran dan bahan pertimbangan untuk menjalani kehidupan kedepan. Ibu tunggal memiliki keinginan merubah kehidupannya menjadi lebih baik dari sebelumnya. Mereka memiliki rencan untuk masa depannya, misalnya untuk membangun keluarga kembali. Mereka tidak memikirkan perkataan negatif yang tidak membangun dan menerima nasehat membangun untuk diri mereka. Menurut penjelasan dapat diketahui bahwa ibu tunggal memiliki 
kepuasan hidupnya sekarang sebagai ibu tunggal.

Keadaan mereka sebagai ibu tunggal dewasa muda yang bercerai tidak lepas dari adanya permasalahanpermasalahan yang harus dihadapi. Permasalahan yang menimpa mereka adalah permasalahan ekonomi serta permasalahan sosial berupa adanya komentar negatif yang tertuju pada mereka. Seperti yang dikemukakan oleh Kaneez (2015) menyebutkan bahwa perempuan yang bercerai akan menghadapi kesulitan yang hampir sama, yaitu mengenai sosial, keuangan, emosional maupun kesehatan.

Dalam menghadapi permasalahanpermasalahan yang mereka alami. Subjek mendapatkan dukungan dari anak, teman, maupun keluarganya. Hal tersebut membantu subjek dalam menghadapi permasalahan yang terjadi. Hal tersebut dikemukakan oleh Selain itu Compton dan Hoffman (2013) menyebutkan bahwa relasi sosial yang positif berupa dukungan sosial dan kedekatan emosional menjadi faktor yang dapat mempengaruhi SWB. Adanya dukungan sosial dapat membuat ibu tunggal mampu mengembangkan harga diri, meminimalkan masalah psikologis, kemampuan memecahkan masalah, serta menjadikan ibu tunggal sehat secara fisik. Selain adanya dukungan, subjek juga memiliki strategi untuk menghadapi permasalahan-permasalahan mereka dengan berpikir positif, berdoa, ataupun menyibukkan diri. Hal tersebut sejalan dengan pendapat Desi, Prabowo, dan Adi (2018) terdapat beberapa cara dalam mengatasi permasalahan perasaan negatif yaitu dengan cara berdoa, curhat, ataupun melakukan kegiatan positif. Menurut Kholidah dan Alsa (2012) berpikir positif dapat menurunkan stres psikologis. Dengan berpikir positif maka diharapkan dapat mengalami proses pembelajaran.

\section{Simpulan dan Saran}

Simpulan

Berdasarkan penelitian maka didapatkan simpulan sebagai berikut:

1. Subjek merasa senang dengan keadaannya sebagai ibu tunggal, bahagia, bangga karena dapat membesarkan anak dengan baik, bersyukur karena anak yang berhasil dibesarkan dapat berprestasi, dan semangat beraktivitas demi anaknya.

2. Subjek merasa khawatir dengan kemampuannya membesarkan anak ketika hendak bercerai, mereka juga khawatir untuk memiliki keluarga kembali, marah dengan mantan suaminya, sedih, merasa iri dengan dengan keluarga yang utuh, serta tertekan dengan keadaannya.

3. Rasa kepuasan hidup terlihat dari mereka yang menerima keadaan sebagai ibu tunggal, menerima masa lalu dengan tidak menaruh dendam dengan mantan suaminya dan menjadikan masa lalu sebagai pertimbangan, memiliki rencana untuk kehidupan di masa depan, misalnya untuk membangun keluarga kembali, ingin merubah kehidupannya menjadi lebih baik dari sebelumnya, dan tidak memikirkan perkataan negatif yang tidak membangun dan menerima nasehat membangun untuk dirinya.

4. Permasalahan yang mereka alami adalah permasalahan ekonomi dan sosial. Permasalahan ekonomi ekonomi terjadi karena mereka memenuhi kebutuhan mereka dan anak-anaknya sendiri tanpa ada bantuan dari mantan suaminya. Masalah sosial yang mereka hadapi adalah adanya komentar-komentar negatif dari orang-orang disekitar mereka mengenai keadaan mereka sebagai janda.

5. Adanya keluarga, teman, dan anak membantu mereka menghadapi 
permasalahan-permasalahan mereka dengan memberi dukungan.

6. Mereka juga tetap berusaha berpikir positif, berdoa, berusaha, dan menyibukkan diri agar tidak terlalu memikirkan permasalahan mereka.

Saran

1. Bagi Subjek

Subjek harus tetap mempertahankan atau meningkatkan afek positif dan kepuasan hidup dalam dirinya. Afek positif dan kepuasan hidup yang baik akan membuat subjek merasakan kesejahteraan yang lebih baik lagi.

2. Bagi Peneliti Selanjutnya

Peneliti selanjutnya hendaknya memperluas batasan wilayah generalisasi, karena penelitian ini hanya dapat digeneralisasikan di cakupan wilayah penelitian.

\section{Daftar Pustaka}

Aisyah. (2012). Dampak psikologis dan mekanisme coping perempuan pasca perceraian. Jurnal Psikosains, 4(2),7994.

Ayuwanty, F., Mukyana, N., \& Zainuddin, M. (2018). Prestasi belajar anak dengan orang tua tunggal. Jurnal Pekerjaan Sosial, 1(2), 148-157.

Badan Pusat Statistika. (2018). Statistik indonesia statistical yearbook of indonesia 2018. Jakarta: CV Dharmaputra.

Compton, W. C. \& Hoffman, E. (2013). Positive psychology the science of happiness and flourishing. USA: Wadsworth Cengage Language.

Desi., Prabowo, A., \& Adi, B.P.A. (2018). Well being dan strategi koping: studi sosiodemografi di getasan. Jurnal Ilmu Keperawatan dan Kebidanan, 9(1), 21-30.

Diener, E. (2009). The science of well being the collected works of ed diener. USA: Springer. Hawkins, D. N. Dan Booth, A. (2005). Unhappily ever after: effects of long-term, lowquality marriages on well being. Oxford Journal, 84(1), 451-471.

Herdiansyah, Haris. (2015). Metodologi penelitian kualitatif untuk ilmu psikologi. Jakarta: Salemba Humanika.

Julijanto, M., Masrukhin, M., \& Hayatuddin, Ahmad K. (2016). Dampak perceraian dan pemberdayaan keluarga studi kasus di Kabupaten Wonogiri. Jurnal Studi Gender dan Anak: Buana Gender,1(1), 55-77.

Kaneez, S. (2015). Perception of subjective well-being among divorced women:a comparative study of hindus and muslims. Pakistan Journal of Social and Clinical Psychology,13(2), 67-71.

Kholidah, E. N., \& Alsa, A. (2012). Berpikir positif untuk menurunkan stres psikologis. Jurnal Psikologi, 39(1), 6775.

Nisa, K., \& Lestari, S. (2016). Dinamika psikologis hardiness pada ibu sebagai orang tua tunggal karena perceraian. Journal Personality and Social Psychology,42(1), 168-177.

Panca, I. (2018). Wow, tiga ribu pasangan di wonogiri bercerai. wonogiri.sorot.co/berita-3424-wowtiga-ribu-pasangan-di-wonogiribercerai.html, diakses pada 13 Oktober 2018.

Ranta, M. (2015). Pathways to adulthood developmental tasks, financial resources and agency. Pekka Olsbo: University Library of Jyvaskyla.

Republik Indonesia. Undang-Undang Nomor 1 Tabun 1974 Tentang Perkawinan. Jakarta: Sekretaris Negara Republik Indonesia.

Santrock, J. W. (2012). Life-span development fourteenth edition. United States: Mc Graw Hill.

Shields, M. \& Wooden, M. (2003). Marriage, children, and subjective well-being. 
Australian Institute of Family Studies Conference.1-21.

Snyder, C.R., \& Shane J. Lopez. (2007). Positive psychology the scientific and practical explorations of human strengths. London: Sage Publications.

Wiranti,. \& Sudagijono, J.S. (2017). Gambaran subjective well-being pada single. Jurnal Experientia, 5(1), 69-80 